\title{
A PRÁXIS DE ESTAR COM: A PEDAGOGIA DO OPRIMIDO E AS MÚLTIPLAS FACES DA CONSTRUÇÃO COLETIVA
}

\author{
THE PRAXIS OF BEING WITH: THE PEDAGOGY OF \\ THE OPPRESSED AND THE MULTIPLE FACES OF THE \\ COLLECTIVE CONSTRUCTION
}

\section{LA PRAXIS DE ESTAR CON: LA PEDAGOGÍA DEL OPRIMIDO Y LAS MÚLTIPLES CARAS DE LA CONSTRUCCIÓN COLECTIVA}

\author{
Maria Clara Pereira Santos ${ }^{1}$ \\ ORCID: http://orcid.org/0000-0003-0411-186x \\ André Ferrer P. Martins ${ }^{2}$ \\ ORCID: $h$ ttp://orcid.org/0000-0001-7719-5043
}

\begin{abstract}
Resumo: Este artigo tem o objetivo de fazer uma releitura da obra Pedagogia do Oprimido, visibilizando o sentido conceitual do estar com dessa obra a partir da vivência no grupo de estudos Práticas Educativas em Movimento e de uma pesquisa bibliográfica que tanto envolve a obra relida como a práxis pedagógica de Marta Maria Castanho Almeida Pernambuco, antiga responsável por esse grupo. Assim, pergunta-se: o que nos oferece a visibilização desse conceito-vivência? A vivência enraizadora, fundo comum aos demais sentidos conceituais da obra em questão, será usada para trazer à tona as contradições que envolvem a violência silenciosa, fenômeno da contemporaneidade que gera novas elaborações de opressões. Ao mesmo tempo, tal vivência enraizadora será usada para expor a construção do conhecimento a partir da experienciação do estado de estar com, ação ética relacional que parece ser a resposta para os efeitos da violência silenciosa. Desse modo, a releitura proposta foca na relação necessária entre a construção do estado de estar com e a busca pela restauração da intersubjetividade, objetivo que Freire (2011) expõe na Pedagogia do Oprimido como função da práxis que a obra traz, sendo a visibilização do estar com como resposta a tais contradições os achados desta pesquisa. Para esse fim, utilizamos uma base teórica freiriana e a construção do diálogo entre essa base e outros pensadores críticos, que nos ajudam a construir uma releitura coerente com a criação de um conhecimento epistêmico-gnosiológico propulsor da libertação dos seres humanos.
\end{abstract}

Palavras-chave: Pedagogia do Oprimido. Práticas Educativas em Movimento. Práxis Pedagógica. Intersubjetividade.

1 Universidade Federal do Rio Grande do Norte, Natal - RN, Brasil

2 Universidade Federal do Rio Grande do Norte, Natal - RN, Brasil 
Abstract: This article aims to do one reinterpretation of the opus Pedagogy of the Oppressed, showing the conceptual meaning sense of being with in this work from the experience in the study group Práticas Educativas em Movimento and from a bibliographical research which involves a reread of this opus, as well the pedagogical praxis of Marta Maria Castanho Almeida Pernambuco, formerly coordinator of this group. Thus, the question is: what offers us the visibility of this concept-experience? The rooting experience, a common background to the other conceptual meanings of the opus, will be used to elicit the the contradictions that involve silent violence, a phenomenon of contemporaneity that generates new elaborations of oppressions. At the same time, this rooting experience will be used to expose the construction of knowledge from the experience of the state of being with, an ethical relational action that seems to be an answer to the effects of silent violence. Thus, the proposed re-reading focuses on the necessary relation between the construction of the state of being with and the search for the restoration of intersubjectivity, an objective that Freire (2011) exposed in Pedagogy of the Oppressed as a function of the praxis that the opus brings, being the visibility of the being with as a response to such contradictions the findings of this research. To achieve this goal, we used a Freireian theoretical basis and the construction of the dialogue between this base and other critical thinkers who help us to build a reinterpretation coherent with the creation of an epistemic-gnosiological knowledge that drives the liberation of human beings.

Keywords: Pedagogy of the Oppressed. Práticas Educativas em Movimento. Pedagogical Práxis. Intersubjectivity.

Resumen: Este artículo tiene como objetivo volver a leer el trabajo Pedagogía del Oprimido, mostrando el sentido conceptual de estar con de esto trabajo a partir de la experiencia en el grupo de estudios Prácticas Educativas en Movimiento y de una investigación bibliográfica que involucra tanto el trabajo retransmitido, como el praxis pedagógica de Marta Maria Castanho Almeida Pernambuco, ex responsable de este grupo. Por lo tanto, la pregunta es: ¿qué nos ofrece la visibilidad de este concepto-experiencia? La experiencia de enraizamiento, terreno común a los otros significados conceptuales del trabajo en cuestión, se utilizará para resaltar las contradicciones que implican la violencia silenciosa, un fenómeno contemporáneo que genera nuevas elaboraciones de opresión. Al mismo tiempo, dicha experiencia de enraizamiento se utilizará para exponer la construcción del conocimiento a partir de la experiencia del estado del estar com, acción ética relacional que parece ser la respuesta a los efectos de la violencia silenciosa. Por lo tanto, la nueva lectura propuesta se centra en la relación necesaria entre la construcción del estado del estar com y la búsqueda de la restauración de la intersubjetividad, un objetivo que Freire (2011) expone en la Pedagogía del Oprimido en función de la praxis que trae el trabajo, siendo la visibilidad del estar com como respuesta a tales contradicciones los hallazgos de esta investigación. Para este fin, utilizamos una base teórica freireiana y la construcción del diálogo entre esta base y otros pensadores críticos, que nos ayudan a construir una lectura coherente con la creación de un conocimiento epistémico-gnosiológico que impulsa la liberación de los seres humanos.

Palabras clave: Pedagogía del Oprimido. Prácticas Educativas en Movimiento. Praxis pedagógica. Intersubjetividad.

\section{INTRODUÇÃO}

Falar e pensar na Pedagogia do Oprimido é falar e pensar sobre a trajetória de Paulo Freire e como ela se desdobra nessa obra, uma vez que essa pode ser colocada como a obra central de Freire. E o que nos diz esse texto que nos esclarece esse estado de estar com que é um lugar tanto teórico como uma prática, uma vez que é um ponto de orientação epistemológico na obra de Paulo Freire, como veremos, e, ao mesmo tempo, uma ação concretizadora do princípio de ação para a transformação, um conceito-vivência? Essa per- 
gunta nos parece pertinente para explorarmos um texto que é filosoficamente um labirinto informativo que está a todo tempo se construindo.

A razão do uso da metáfora do labirinto que se autoconstrói é uma tentativa imagética em lidar com a complexidade do teor dessa obra, pois, como os conceitos que dão identidade a ela não podem ser desatrelados de vivências concretas que dão sentido a esses conceitos, esses sentidos só podem ser lidos ou compreendidos a partir de outras vivências que tragam sentidos de interação, não de semelhança, mas de reconhecimento de um lugar-comum. $E$ isso é tão significativo que marca uma característica daqueles que se propõem a lidar com questões várias a partir do horizonte conceitual de Freire. A realidade vivida, o espaço-tempo onde a história se faz, é o fundo comum onde acontece o encontro significativo dessa obra, daí a afirmativa de que existem várias, infinitas formas de a dizer que a tornam móvel, atual a todos os contextos que se fazem por filamentos-sentidos comuns.

Coerente a isso, a metodologia adotada neste artigo foi a dialética negativa, dada a necessidade de se trabalhar com um horizonte de sentido que visibiliza o conceito do estar com em sua dupla face prática/teórica, uma vez que é objetivo de nosso trabalho visibilizar esse conceito como um ângulo basilar da Pedagogia do Oprimido. Uma vez que esse conceito é germinado pela ação da relação dos eus com os outros, há necessidade da construção de uma constelação de sentidos não cindidos da realidade concreta, sendo, aqui, essa realidade vivida no Ateliê Práticas Educativas em Movimento, antes coordenado por Marta Maria Castanho Almeida Pernambuco. Tal realidade será trazida com o objetivo de expor o ângulo do estar com não só como um conceito indicador de um ponto de orientação da obra de Freire, mas também um lugar pedagógico libertador.

A metodologia dialética negativa é usada para dar forma a um conceito que ilumina um objeto sem o prender à univocidade conceitual restritiva, de maneira que tal metodologia tem como um dos elementos característicos trabalhar com constelações de sentidos que iluminem as nuanças de um objeto não cindido do seu lugar de formação, a realidade (PUCCI, 2012). Daí a importância de se usar uma metodologia que tem como poder estimular o ir além de conceituações positivistas, em busca daquilo que seria reprimido no processo de conhecimento totalizante (PUCCI, 2012).

Somado a essa finalidade epistemológica, este artigo traz também consigo um sentido amoroso que é fazer parte da construção da memória de Pernambuco, mulher freiriana que esteve com tantos outros lutando pela transformação de nossa realidade social, fazendo parte do tecer freiriano. Por isso, a importância de trazer sua prática como um lugar de vivência fenomênico de onde eclode, por meio da análise crítica, os múltiplos sentidos que dão vida ao que é apresentado na obra de Freire, Pedagogia do Oprimido (2011), como o estar com. 


\section{O ESPAÇO DO ATELIÊ PRÁTICAS EDUCATIVAS EM MOVIMENTO COMO UM EXPOSITOR DOS VÁRIOS ÂNGULOS DO QUEFAZ9ER NA PEDAGOGIA DO OPRI-} MIDO

Toda tentativa de releitura da Pedagogia do Oprimido pede um romper minimamente com certos grilhões do processo de hegemonização. Para se romper com algo é necessário primeiramente que tomemos consciência dos elementos que envolvem o que se deseja romper, para que, a partir da consciência "de", se possam construir estratégias para o rompimento, de fato, "com" (FREIRE, 2011). Por sua vez, essa tomada de consciência parece vir de um estado de agenciamento de uma ação refletida: faço em alerta crítico, problematizo minha ação, delibero sobre ela, possibilito uma ação mais consciente.

Esse fazer-refletir-deliberar-agir-consciente, ou melhor, a ação-reflexão-ação, faz parte de um estado de transição, ou trânsito, em que uma coletividade, anunciando novos meios de lidar com a realidade, encontra novos temas, novas tarefas, que, por sua vez, de acordo com Costa (2016, p. 409), formam "novos dispositivos mentais" (BARBU, 1998 apud COSTA, 2016, p. 409). Na verdade, Costa explica, no Dicionário Paulo Freire, que o estado de transitividade impõe um esvaziamento dos sentidos coletivizados das antigas estruturas de organização, ao passo que constrói novos sentidos. Esses sentidos novos, chocando-se com os sentidos coisificadores, expõem as contradições sociais via o acirramento destas (COSTA, 2016).

O estado de transitividade acontece em esferas diferentes: no indivíduo social, pelo romper de um olhar ingênuo que dá lugar a um olhar crítico; acontece em uma coletividade quando consegue construir em conjunto de estados de concretude do romper; acontece nas sociedades quando toda a sociedade ruma para novas fases históricas; e, o mais importante, há nesse acontecimento de transitividade uma necessidade de estar com, pois, mesmo existindo um estado de transitividade do indivíduo, esse só se faz em coletividade, só sé faz no encontro entre os vários diferentes que, somando-se, sem a reprodução da anulação do outro diferente por meio do estar com no diálogo crítico (FREIRE, 2011), criam meios de construir temas, metaespaços comuns onde se elabora o novo, que expõe a "[...] decisão e compromisso de colaborar na construção do mundo comum" (FREIRE, 2011, p. 28).

Esse estado de estar com, que aqui visibilizamos em seu duplo sentido (prático/teórico), acontece porque "Os temas, em verdade, existem nos homens, em suas relações com o mundo, referidos a fatos concretos" (FREIRE, 2011, p. 137). Dessa forma, é importante salientar que o estado de transição do indivíduo impõe um sair do seu estado individualista para aprender a lidar com a individuação. Isso significa uma ação dialógica tal que pressupõe uma escuta, uma fala, um fazer-ser-mais em conjunto, com os tantos outros diferentes. Por isso, Freire (2003) fala em uma transitividade social. 
No trânsito social, co-habitam alongamentos da sociedade velha e adentramentos da sociedade nova, ou seja, elementos contraditórios de modelos sociais em conflito. [...] Isso ocorre em função das massas iniciarem, durante o trânsito, a sua saída da cultura de silêncio. Entretanto, subsiste nesse novo estilo de vida política o caráter manipulador da consciência das massas por parte dos líderes políticos. Contrastando com o desvelamento da realidade que já se encontra em curso (COSTA, 20116, p. 409).

A educação, nesse processo de transitividade, possibilita a germinação dos meios do trânsito tal que ela, se não bancária, se libertadora, permite ao indivíduo redescobrir um mundo onde as significações não são determinantes externos, mas constituintes de uma intenção socializante, por promover encontros entre os individuais que significam o mesmo mundo (FREIRE, 2011). Ela promove a abertura de um espaço que surge como vivência profunda de fundo comum. Esse fundo, ao ser codificado e descodificado, faz surgir um novo mundo de encontro, faz surgir a liga de toda situação de mudança em prol da emancipação dos sujeitos, um vivenciar com, como afirmou Paulo Freire na sua obra Pedagogia do Oprimido (2011).

É o homem novo pensado por Freire, cuja posição crítica, ativa e dialógica do mundo revela suas origens enraizadas no processo de libertação. Encontra fundamento e autenticidade no movimento de vir a ser, marca da incompletude de quem se constrói, individual e coletivamente, no movimento histórico de busca pela humanização solidária de todos (PITANO, 2016, p. 385).

No modo de organização desumanizante, o estado relacional ontológico do humano é negado por estruturas negligenciadoras da não dicotomia da intencionalidade. Isso resulta em uma dicotomização também do lidar, ou entender, da consciência. Ao contrário do que as estruturas heteronômicas naturalizam, não obstante, no processo de reflexão humana, em que a intencionalidade humana se faz-ser, quando a consciência se distancia para dar forma ao intencionado, promovendo o distanciamento, acontece a objetivação do mundo e ao mesmo tempo a presentificação do mundo pela intenção. "Nessa linha do entendimento, reflexão e mundo, subjetividade e objetividade não se separam" (FIORI, 2011, p. 20). Da mesma forma que a identidade de ser um eu presume a alteridade do outro (TROMBETTA, 2016).

Logo entendemos que Freire (2015b), ao falar do estado de tomada de consciência, coloca como prerrogativa um se perceber "com", um vivenciar o estado de estar em relação, não em uma igualdade opressiva, mas uma diferenciação tensora que deve culminar em um se projetar com para além dos horizontes pré-estipulados. "O termo relação indica o próprio do homem frente ao mundo, que é estar nele e com ele, com um ser do trabalho, da ação, com que transforma o mundo" (FREIRE, 2015b, p. 112).

A germinação desse estado de se construir com, de criar espaços de encontro por meio de uma episteme-gnosiológica que tenha uma significação para além da instrumenta- 
lidade desumana, implica em uma consciência socializadora, tal que o [re]descobrir o mundo saindo do horizonte heteronômico envolve uma situação gnosiológica "[...] em que o ato cognoscente não termina no objeto cognoscível, visto que se comunica a outros sujeitos, igualmente cognoscentes" (FREIRE, 2015b, p. 78).

A intersubjetividade, elemento relacional que condiciona a subjetividade a um reconhecimento do outro, promove a circularidade do vivido-re-vivido compartilhado: "não há eu que se constitua sem um não eu, por sua vez, o não eu constituinte do eu se constitui na constituição do eu constituído" (FREIRE, 2011, p. 99). Conseguintemente, "Subjetividade e objetividade se encontram em uma unidade dialética que resulta um conhecer solidário com o atuar, e este com aquele, não se pode pensar uma sem a outra" (LOSSO, 2016, p. 231). Essa cognoscibilidade coparticipativa leva continuamente a um rever o modo de compreender o mundo experimentando o estado de mediação no devir ontológico humano. Temos, então, um conceito em sua duplicidade de sentido: de um lado, o sentido teórico aqui exposto e, de outro, o sentido prático sinalizado pelo sentido teórico, mas que só pode ser apresentado com a exposição de uma situação histórica presentificadora desse outro sentido, que será trazida logo adiante.

Nos espaços acadêmicos se prolifera uma produtividade vazia de sentidos concretos, tendo em vista que muitas vezes a produtividade acadêmica não está atrelada ao rompimento das situações de contradição da sociedade que povoa o entorno dos espaços universitários, levando a uma verborragia epistemológica que reproduz a ideologia da neutralidade do produto científico. Nessa direção, o trabalho da Profa. Dra. Marta Maria Castanho Almeida Pernambuco, na Universidade Federal do Rio Grande do Norte, encarnando a práxis da coletividade libertadora freiriana, promoveu com o Grupo de Estudos e Práticas Educativas em Movimento (GEPEM) o desmoronamento dos muros ocultos do espaço universitário, tornando possível não só a germinação da consciência coletiva nos vários indivíduos que passaram pela disciplina Ateliê de Práticas Educativas em Movimento, mas também a proliferação das falas de muitos silenciados pelo espaço universitário.

As falas de mundo que encontraram um lugar de vivência do estado relacional no espaço construído palas práticas libertadoras do estado de com de Pernambuco testemunham a necessidade da construção desses metaespaços de alteridade relacional. Logo, é entendido que devemos partir dela para expormos novos anúncios, por tal realidade visibilizar, dentro de conjunturas complexas, como o estado relacional infere um se inteirar da alteridade do eu com o outro. Por isso, é esse lugar histórico usado para dar visibilidade à dimensão prática do estar com em Freire. Lembremos que

Se o que caracteriza os oprimidos, como "consciência servil" em relação à consciência do senhor, é fazer quase objeto e transformar-se [...] em consciência para o outro, a solidariedade verdadeira com eles está em com eles lutar para transformação da realidade objetiva que os faz ser este "ser para o outro" (FREIRE, 2011, p. 49). 
Assim, será a realidade do Ateliê fundo problematizador em prol da compreensão de como a conscientização do estado relacional na situação gnosiológica é um dos elementos-chave para a transitividade, e por isso está implícita no quefazer das práticas freirianas. Tal que o relacional se expõe na práxis pedagógica exercitada nessa realidade como uma experienciação do inteirar-se alterador, que, para Freire (2001), não produziria um conhecimento meramente epistemológico, mas um conhecimento relacional, isto é, um conhecer inteirado do eu com o outro.

\subsection{ATELIÊ DE PESQUISA PRÁTICAS EDUCATIVAS EM MOVIMENTO}

O Ateliê de pesquisa Práticas Educativas em Movimento é um espaço em que o grupo GEPEM não só compartilha seus conhecimentos freirianos produzidos como também os que são produzidos por outros grupos vinculados à Cátedra Paulo Freire, tendo como base sempre os conhecimentos da própria obra de Freire. Além disso, esse espaço promove, acima de tudo, o exercício de estar com, uma vez que, mesmo existindo variações de objetivos distintos, ao passar dos semestres e da formação de membros do grupo, mantém-se como eixo central das atividades desse espaço - nos quatro anos que pude participar assiduamente do grupo - o exercício do se perceber-fazer em conjunto.

O GEPEM, grupo que dá base de sustentação ao Ateliê, dentro das estruturas macro da Cátedra, se propõe a produzir sistematicamente pesquisas que abordem "[...] a indissociabilidade do processo-produto [...]" (DELIZOICOV; ZANETC, 1993, p. 9) no fazer currículos como

[...] momento participativo de planejar e organizar as programações e práticas, pois é aí que os interesses e as intencionalidades político pedagógicas tornam-se coletivamente consciente e explicitas, evidenciando os critérios adotados para a seleção dos conhecimentos sistematizados e as metodologias que promoverão o percurso que se prende implementar no processo de ensino-aprendizagem. Trata-se de uma proposta de formação permanente que visa desencadear junto ao grupo-escola um posicionamento crítico-prático em relação às necessidades e às contradições por ele vivenciadas e os encaminhamentos concretos para a conquista da autonomia. (GOUVÊA, 2013, p. 75).

O currículo é abordado nessa perspectiva como algo encarnado de mundo social por ser entendido como produto de um conjunto de práticas socioculturais, filamentos tecedores que "[...] se inter-relacionam nas diferentes instâncias e momentos do espaço/tempo escola, assumindo uma intenção pedagógica emancipadora na prática educativa convencional" (GOUVÊA, 2013, p. 6-7).

Há, por trás desse processo de fazer currículo, uma interdisciplinaridade que leva as particularidades dos conhecimentos específicos sempre atreladas ao lugar do sujeito conhecedor - suas raízes identificativas -, ganhando uma contextualização de tal modo 
que as contradições instituídas no bojo social-produtor desses conhecimentos e endereçadores dos sujeitos conhecedores emergem como produções de conflitos socializantes. A visibilização dos conflitos é usada aí não só como elemento de internalização significativa dos conhecimentos novos, mas também no uso desses conhecimentos para o revolver das situações de negação do sujeito silenciado, visto que é na visibilização dos conflitos endereçadores que os sujeitos se descobrem compartilhadores de sentidos significantes comuns - construindo um estado de ser no mundo, eles se descobrem criadores e não objetos (FREIRE, 2011).

O reconhecimento dos sentidos compartilhados, dentro do mundo que também se coloca como um estado de com, embutido nesse horizonte libertador freiriano, se faz pela experimentação da realidade local e sua relação com um todo social, pela vivência das situações de fundo, comuns a todos, pela sistematização de teias temáticas expositoras do real vivido, que é esse fundo compartilhado, em relação ao todo estruturante. O real vivido, nesse sentido, é espaço de problematização germinadora do ser-mais deliberador que vive nesse fundo, agente ativo de sua mudança que se entende no mundo e com ele. Estamos lidando com um novo paradigma educacional, como assevera Gouvêa (2013), um paradigma que leva a um modo característico de lidar com o ensino, como afirma Pernambuco (2013) ao se referir a esse tema. Tal paradigma educacional leva a uma compreensão do "[...] ensino como uma atividade humana historicamente mutável e referenciada, ocorrendo dentro de uma dinâmica social e dos indivíduos particulares nela envolvidos [...]" (PERNAMBUCO, 2013, p. 57).

Estamos, portanto, considerando que a educação, apesar de não ser o elemento determinante, pode ser um instrumento importante para ocorrência de transformações sociais e para isso precisa dar ao educando acesso ao conhecimento que permita agir sobre o mundo em que vive; uma inserção local em uma sociedade complexa em constante mutação. O que implica um repensar dos seus conteúdos, tanto do ponto de vista de quais instrumentos fornecem aos educandos, quanto de como interagem com as necessidades e possibilidades pessoais e grupais deles e dos educadores. (PERNAMBUCO, 2013, p. 58).

"Necessidade de contextualização", "partir dos conhecimentos prévios dos alunos", as palavras aqui proferidas podem vir de um lugar comum do vocábulo pedagógico, contudo, por trás do sentido de educação libertadora freiriano existe um modo de lidar com os sujeitos do conhecimento e com o conhecimento, existe um exercitar, o que Delizoicov e Zanetic (1993) explicam em seu texto "A proposta de interdisciplinaridade e o seu impacto no ensino municipal de $1^{\circ}$ grau" como um sair da inércia da tradição, que é proporcionado por uma ação integradora que fia a vivência do sujeito e o mundo concretizado pela coletivização, o levando a perceber-se relacional. A integração aqui parece se mostrar como a chave da práxis freiriana, posto que ela se torna o fio tecedor de todos os momentos de 
construção de um tempo/espaço novo, o tempo/espaço do reconhecer a vivência do com; processo de se descobrir vivente histórico relacional, e por isso em seu movimento de criação de reconhecimentos plurais de ser-mais.

Pernambuco, nesse horizonte praxiológico, sai do lugar de professora reprodutora e expõe uma vida de exercício do estar com, sendo sua trajetória marcada não só pela presença da obra de Paulo freire, mas pela vivência com os movimentos sociais, pela vivência com os parceiros na construção dos projetos de transformação freiriana, pela vivência com seus tantos educandos-educadores. O estado de estar com é visibilizado também no contínuo engajamento que Pernambuco manteve, estando desde a década de 1970 trabalhando ativamente na construção, propagação e práxis freiriana. "Podemos afirmar, sem sombra de dúvidas, que Marta é o que Gramsci denominaria 'intelectual orgânica da classe trabaIhadora'" (GOUVÊA et al., 2018, p. 20). Esse adjetivo é trazido por um artigo que tem como objetivo não só resgatar a trajetória de Pernambuco em relação à educação do campo, mas visibilizar as contribuições que ela, em sua trajetória de vida, deu para a educação do campo.

Nessa entrevista, Demétrio Delizoicov (GOUVÊA et al., 2018), em suas falas sobre Pernambuco, expõe um quefazer freiriano que aparenta ser característica da ação educacional de Pernambuco, maturado por sua vivência com os tantos que participaram de sua trajetória de vida. Esse quefazer, ao partir da compreensão pedagógica e educacional libertadora, pressupõe "um estudo da localidade onde se desenrola a ação educacional" (GOUVÊA et al., 2018, p. 23). Sobre isso, Delizoicov irá explicar que

O que denominei, por enquanto, de "estudo da localidade" trata de se aproximar tanto das condições materiais de vida das pessoas que vivem numa localidade, não importa se urbana ou rural, e, sobretudo, um esforço de em equipe obter através da fala dessas pessoas como elas compreendem essas condições, em particular as problemáticas. (GOUVÊA et al., 2018, p. 23).

Dentro do espaço acadêmico, essa práxis pedagógica engajada em germinar uma ética de transformação ganha traços característicos que podem ser melhor expostos na fala, ainda nessa entrevista de Irene Alves Paiva (GOUVÊA et al., 2018), que afirma que Pernambuco, como parte do corpo docente da UFRN, "[...] sempre teve preocupação e compromisso com a construção de uma universidade democrática, inclusiva, à qual os setores populares tivessem acesso" (GOUVÊA et al., 2018, p. 24). A necessidade de tornar o espaço universitário inclusivo trazia um modo não tradicional de lidar com a construção do conhecimento científico, sendo esse modo tradicional caracterizado aqui como uma produção em que existe o retentor do poder de produzir conhecimento e, do outro lado, existe o recipiente esvaziado de seu conhecimento de mundo, que é visto como meio, objeto para fins monolíticos epistemológicos. Na contramão dessa epistemologia tradicional, temos a produção do conhecimento relacional em que "[...] dar-se na relação entre sujeitos, entre 
indivíduos, entre organismos - entre 'corpos conscientes' [...]. Essa relação gera uma dimensão ética" (BECKER, 2016, p. 153).

No modo de construção do conhecimento que parte de um quefazer repleto de sentido ético transformador, não existirá um eu determinado a se ajustar às estruturas opressivas. Pelo contrário, haverá uma práxis vivenciadora de modos de produção libertadores do ajustamento naturalizado, produto de um reconhecimento em que todos são donos de uma voz, de um falar que é parte do fazer concretizado na história social. Há, aí, um processo de construção de conhecimento a partir do diálogo como elo-motor. Visto que

\begin{abstract}
A capacidade cognitiva humana assim concebida gera a pergunta, a curiosidade, a ação exitosa (prática), a ação refletida (práxis), o diálogo, a liberdade, a autonomia, a transcendência, a utopia, a aprendizagem transformadora, a totalidade. Ela cria horizontes em que é possível inventar e criar o novo; em que não se é condenado a repetir o antigo; em que se faz história (BECKER, 2016, p. 154).
\end{abstract}

Isso, por sua vez, pressupõe um lidar com um tempo não no sentido funcional, mas lidar com um tempo de todos e de cada um, lidar com o tempo da produção coletiva, do encontro entre os singulares formando um coletivo socializante (FREIRE, 2011). Pressupõe também um lidar com as marcas históricas de todos de tal forma que seus endereçamentos sejam trazidos para o quefazer gnosiológico.

Nesse entrelaçamento entre o tempo e espaço sensível aos sujeitos em suas ações de tecedura, é o fazer coletivo que implica a vivência da tomada de consciência do estar com, visibilizando, por conseguinte, os endereçamentos sociais que formam o lugar de fala, a referência cultural, o modo de ver o mundo, posto que modela as lentes singulares que levam a uma compreensão compartilhada por aqueles que vivenciam as mesmas referências enraizadoras. É esse compartilhamento que torna possível o reconhecimento, pois só é possível o reconhecimento à medida que eu e o outro nos reconhecemos em um fundo comum (FREIRE, 2011). "E é por isso que, minimizado e cerceado, acomodado a ajustamentos que lhe sejam impostos, sem o direito de discuti-los, o homem sacrifica imediatamente a sua capacidade criadora" (FREIRE, 2003, p. 50). Coerentemente,

[...] a educação ou a ação cultural para a libertação, em lugar de ser aquela alienante transferência de conhecimento, é o autêntico ato de conhecer, em que os educandos - também educadores - como consciências "intencionadas" ao mundo ou como corpos conscientes, se inserem com os educadores - educandos também - na busca de novos conhecimentos, como consequência do ato de reconhecer o conhecimento existente. (FREIRE, 2015a, p. 163).

Sendo o Ateliê Práticas Educativas em Movimento um espaço onde o processo de desenraizamento é problematizado pelo quefazer freiriano, aqueles que passaram - e passam - por lá têm a possibilidade de lidar com um tipo de pedagogia do movimento, proces- 
so de aprendizagem marcado por um fazer integrador que proporciona uma experienciação temporalizante. Dizemos que essa foi a marca deixada por Pernambuco para o grupo.

Na realidade desse espaço de encontro, é a fala desse outro que determina o tempo. Tal fala se torna um todo trazido como meio enlarguecedor dos horizontes epistemológicos. Eu, formada em filosofia, um curso que normalmente impõe um fazer solitário marcado pelo conviver com as obras clássicas, fui instigada por Pernambuco a me despir do olhar distanciador das falas dos outros, tal que a dinâmica do espaço coordenado por Pernambuco me exigia a sensibilidade de lidar com as singulares referências históricas-sociais do outro, desse que deveria - pela experienciação da alteridade - reconhecer.

Mesmo que esse espaço semestralmente sofresse modificações, dada a movimentação dos sujeitos participantes, éramos estimulados a nos reconhecer como grupo, e como tal encontrar-nos no mundo do com. Isso acontecia por meio da exposição das várias falas repletas de mundo, que nos serviam como pontos de encontros, proporcionando a criação-descoberta de referências compreensivas comuns, a exemplo: o conteúdo a ser proposto no Ateliê era discutido pelo grupo GEPEM e depois discutido também pelo grupo que formaria o Ateliê naquele semestre. O processo de escolha do conteúdo impunha já um exercício de deliberação reflexiva do todo, uma vez que chama à participação. E, nesse momento, as falas de deliberação faziam nos entreolharmos, reconhecendo-nos no outro.

Pernambuco, no primeiro dia de aula, expunha as propostas de trabalho, que semestralmente variavam, a depender do perfil das pessoas que formavam o grupo e das demandas do GEPEM em relação à Cátedra Paulo Freire. Assim, se, em um semestre que éramos um grupo pequeno, fazíamos levantamentos de dados de pesquisa - do Grupo de Estudos e Pesquisas sobre Práticas Educativas em Movimento (GEPEM/UFRN), em outros semestres que o grupo era formado por professores, por funcionárias da Secretaria de Educação do Estado e do Município, além dos participantes do grupo GEPEM, estudávamos as obras freirianas, sempre orientadas por dois nortes: um era a obra Pedagogia do Oprimido, o outro nossa historicidade, nosso lugar de fala, que eram muito explorados nas aulas. Logo, não existia uma discussão conceitual tradicional, em que as palavras são repletas de sentido abstratos; todos éramos estimulados a enchermos nossas palavras de um eu histórico, de um eu encarnado de mundo vivido.

Em um grande grupo ou divididos, em um primeiro momento, em pequenos grupos que depois formariam um grande grupo, passávamos pelos três momentos pedagógicos em que: no primeiro, éramos incentivados a lidar com o limite do nosso conhecimento sobre o tema proposto, que normalmente se referia ao uso e aos sentidos conceituais dispostos nas obras de Paulo Freire e em obras que a ele se referiam; no segundo momento, éramos instigados a superar o limite do nosso conhecimento preliminar sobre o tema estudado, problematizando e pesquisando o que essa problematização indicava como lacuna, investigando os espaços lacunários - "É que, na problematização, cada passo no sentido de aprofundar-se na situação problemática, dado por um dos sujeitos, vai abrindo novos 
caminhos de compreensão do objeto da análise aos demais sujeitos" (FREIRE, 2015b, p. 110).

A pesquisa descrita nos fazia relacionar o tema a um todo temático; no terceiro momento, esse todo temático que é percebido parcialmente pelos grupos menores era levado ao grupo maior e percebíamos os vários fios possíveis entre o tema gerador e o universo que esse tema abria. Isso, por sua vez, nos levava a uma nova postura sobre o tema. Podemos observar que aí existe um fazer-ser epistêmico-gnosiológico com, visto que os saltos de compreensão se fazem como resultado da ação-reflexão-ação intersubjetiva.

Como pode ser deduzido pela descrição supra, todas as atividades impunham um movimento de integração, visto que deveríamos interagir uns com os outros, dialogar, seja esse diálogo construído por etapas, em que grupos menores eram formados para estimular pessoas mais tímidas a falarem, para depois desembocar na formação de um grande grupo. A variação desses momentos era pensada pelo próprio todo, tendo em vista as necessidades distintas de seus lugares lacunários. Os sujeitos em exercício de se perceberem em estado relacional eram levados a vivenciar seu fundo endereçador que se encarnava em sua ação didática e em seus modos de compreender os conteúdos conceituais freirianos. "É nesse momento que a realidade se apresenta ao aluno codificada, necessitando ser descodificada, por meio da aquisição de outras visões" (PERNAMBUCO, 2013, p. 65). Se a codificação se dá no admirar o estado de estar no com, a descodificação se dá na movimento de problematizar o estado de com (FREIRE, 2011), fazendo com que os sujeitos experienciadores se aprofundem na percepção relacional. A problematização aí é a âncora de imersão e emersão intersubjetiva, uma vez que ela "[...] é a tal ponto dialética, que seria impossível alguém estabelecê-la sem comprometer-se com seu processo. Ninguém, na verdade, problematiza algo a alguém e permanece, ao mesmo tempo, como mero espectador da problematização" (FREIRE, 2015b, p. 110).

O modo de análise, mesmo se propondo ser objetiva, ao partir da localização histórica e social, da vivência da temporalidade enraizadora (FREIRE, 2003), gera um estranhamento do como nos colocamos no lugar enraizador para chegarmos na reestruturação do como isso se desdobra no estar com, intersubjetivo. Ao falarmos em um processo temático gerador que se dá em um meio acadêmico de pós-graduação, é interessante salientar que se sobressaia desse processo de construção singular, muitas vezes, a necessidade de se ancorar o sentido deslocador na ética do reconhecimento, uma vez que eclodiam normalmente daquele espaço os sentidos competitivos que tornavam ainda mais ruidosos o exercício de construção coletiva.

A ação de ancoragem na ética do reconhecimento era vista nos exercícios de compreensão de sentido conceitual freiriano ao problematizarmos, frequentemente, o motivo que fazíamos "cortar" uns aos outros, silenciar uns aos outros, expondo uma belicosidade aparentemente autômata ao termos que lidar com a fala do outro. Problematizando esses ruídos, por meio dos sentidos conceituais freirianos, movíamos em direção ao outro pelo 
exercício da escuta e fala respeitosa. Essa imposição de respeito, por sua vez, levava a choques, revisões ideológicas, deslocamentos de compreensões ingênuas, ou mesmo acríticas. Quem se deixava ser tocado pelo modo de aula, pelo sentido de compartilhamento que Pernambuco encarnava em suas dinâmicas como coordenadora integrativa, tinha a possibilidade de aprender mais do que os sentidos dos conceitos na obra de Paulo Freire, tinha a oportunidade de exercitar tais sentidos, de fazer-ser aquilo que era estudado.

Conseguintemente, em muitos momentos do processo de construção do conhecimento de modo coletivo no Ateliê, nós, sujeitos da fala e da escuta, tínhamos que lidar com as situações contraditórias que estavam em torno de nossa fala, pois eclodiam desse lidar com o outro, dentro dessa construção epistêmica-gnosiológica, os traços de rivalidade impregnados na vivência da produtividade vazia de sentido acadêmica. Deparávamo-nos com as situações-limites que formam o endereçamento do intelectual em seu estado de contradição, tínhamos que lidar com as inseguranças que vinham do abrirmos mão das falsas imagens de superioridade intelectual sobre o outro que não tinha os mesmos títulos que nós, uma vez que o Ateliê era um espaço de democratização da academia e, como consequência disso, havia lá a pluralidade do mundo fora do Lattes.

A professora Pernambuco, em muitos momentos em que as tensões se tornavam ruidosas ao ponto de paralisar o exercício de diálogo, ensinava-nos, por intervenções orientadoras, a importância de ser sensível à palavra de mundo do outro, nos indicando, via o esclarecimento epistêmico freiriano, ações reprodutoras de opressões veladas que cometíamos sobe a fala do outro. Essas intervenções nos faziam refletir que o silenciamento do plural empobrecia a potencialidade da pluralidade do grupo. Lembro-me que esse movimento do exercitar a escuta era algo muitas vezes tão pesado para uns, inclusive para mim, que ocorriam situações de conflitos que se tornaram tensões pessoais, e que Pernambuco lidava com elas fazendo com que os sujeitos em estado de tensão se comunicassem, falassem suas queixas uns para os outros, aprendessem a lidar e deliberar sobre suas tensões sem abrir mão do outro.

Nos momentos de tensão em que os egos acadêmicos se acentuavam, não era Pernambuco que tomava o centro e trazia uma solução apaziguadora, mas sim os sujeitos, colocados a falar suas queixas e a escutar as queixas do outro, que deveriam encontrar lugares comuns. Éramos nós, os educandos-educadores, que deveríamos, lidando com nossas tensões, deliberarmos sobre como tratar os impasses, escutando o outro e sendo escutado. A realidade e seus dados, nesses momentos de impasse, tornavam-se os juízes das falas plurais, visto que, em situações em que várias verdades se colocavam em xeque, Pernambuco nos ensinava a investigar o que dizia a realidade, o que dizia o mundo à nossa volta, o que dizia a vivência dos mais experientes no tema e usarmos essas vias integradoras como direcionadores das deliberações.

Então, se falávamos em educação popular e nos pesquisadores que tinham mais "teoria" sobre o tema do que vivências, e entrávamos em conflito sobre sentidos como cír- 
culo cultural, construção em coletividade, dentro outros conceitos que formam essa seara, Pernambuco nos mobilizava a, pela escuta, tornar as falas dos e das colegas educadores populares lugares de aquisição de sentidos informativos. Nós, pesquisadores esvaziados de sentidos do real vivido, ao mesmo tempo em que aprendíamos a visibilizar o outro diferente como iguais em suas diferenças, experienciávamos o desmonte de nossas máscaras de assertividade, pois a vivência dos nossos colegas, quando tornados objetos de sentido informativo reconhecedor, mostrava-nos a fragilidade de nossas formações teóricas. Por outro lado, nossos colegas imersos na prática eram estimulados a pensar as várias contradições que sua realidade poderia indicar, ao ser problematizada pelo grupo. Logo, existia aí um duplo movimento de reconhecimento.

Os colegas que chegavam "verdes" de experiência acadêmica iam se descobrindo pesquisadores, ao passo que íamos, os "verdes" de chão da prática, também os visibilizando como pesquisadores, tomando consciência das teorias por trás de suas práticas, e nos descobrindo possuidores de uma prática. Esse movimento de descoberta da potencialidade do coletivo enquanto formado por sujeitos diferentes que em diálogo se tornam, em vários momentos, um todo reflexivo com poder de responder às suas próprias lacunas internas proporcionava, em muitos momentos, saltos de compreensões, saltos de posturas, deslocamentos de ser.

Na sala de aula não só mergulhávamos nos sentidos conceituais de Paulo Freire, mas exercitávamos seus sentidos-ações ao deslocarmos nossos olhares, ao nos movermos de nossos horizontes-limites e tornarmos o mundo em seu estado de devir o lugar de partida de nossa fala, estimulando-nos a criar sobre esse mundo-fundo. A cada ponto cosido que dávamos, vinculando o abstrato teórico ao real vivido, a cada fiar que construíamos entre a macroesfera distante e a microesfera endereçadora, descobríamos novas curvas moventes, novas instituições reprodutoras, novas possíveis rupturas, novos possíveis modos de sentidos, novos erros cometidos.

Em muitos momentos, o grupo vivenciou o estado de compreensão do conceito que Ihes levava a um perceber que ainda não estávamos lidando com o todo transbordador do sentido do conceito, e isso nos fazia voltar para a problematização sobre o tema, problematizando as estruturas que nos paralisavam a reflexão relacional. Todavia, esse lugar de volta não era um lugar já vivenciado, era um novo lugar de compreensão do diferente não visto. Isso fazia com que alguns sentissem que estávamos nos movendo em uma espiral formada por vários fios que se entrelaçariam à medida que o diálogo interligava nossas compreensões.

O comprometimento com essa práxis epistêmica fazia com que nossas aulas, muitas vezes, circulassem em torno de um único conceito e suas referências temáticas-conceituais por todo o semestre. Esse único referencial ia se desdobrando em uma teia temática onde os conceitos não podiam ser desvinculados de seus lugares de criação de sentido. Então, ao se falar de ser-mais, tanto líamos obras teóricas que discutiam o conceito como exercitá- 
vamos ações coletivas que nos levavam a nos deslocamos de lugares comuns opressivos mutuamente, lugares de silenciamento do diferente, da fala não catedrática que orbitava o sentido conceitual de ser-mais, assim, passávamos não só por toda uma gama de conceitos que montam o sentido de ser-mais, como também pela problematização do nosso próprio agir que se impregnava em nossos movimentos de compreensão.

Existia na aula da professora Pernambuco um movimento de construção de uma realidade nova em que as contradições do espaço que orbitávamos, o espaço acadêmico, não era minimizado, ou ignorado, mas explorado como elemento significativo que ajudava a elucidarmos as dificuldades que surgiam no nosso processo de nos experienciarmos como grupo. Era necessário um olhar o outro, um compreender que o conhecimento do outro também era válido tal qual o seu, e, por isso, deveria ser respeitado e ter espaço de escuta. O outro, por sua vez, era levado a se impor, a conquistar seu espaço de fala com o uso de suas palavras significativas. Não existia aí um movimento de persuasão, mas de sensibilização ética diante do diferente.

A aula tinha um tempo próprio, não era o tempo dos conteúdos, mas o tempo das pessoas, o tempo dos vários eus em seus processos de encontro enraizadores em prol do enlarguecimento dos horizontes epistêmicos e humanizantes. Esse tempo não determinado pela lógica de produção incessante da academia nos proporcionava um espaço de encontro e troca com o outro. O sentir as palavras que vinham do outro era o indicador do passar mais rápido ou mais devagar do tempo, essas palavras repletas de mundo vivido por esse outro nos mobilizavam a uma aprendizagem dos conteúdos propostos por meio da percepção das nossas lacunas ao lidarmos com a descoberta dos sentidos do outro como apresentador de vários sentidos significantes, e por isso afirmo que a base dessa pedagogia em movimento seria uma ética do reconhecimento.

Existia também um cultivo de confiança no outro, não uma esperança cega que não lidava com as contradições do eu e do outro, mas uma tomada de consciência de que, dada a complexidade dos seres humanos e os lugares de fala, os erros e os acertos deveriam ser tornados instrumentos de construção e não de fragilização. Todos nós éramos incompletos, lacunários e carregados de contradição, e só no fazer coletivo, no perceber a diferença em estar com, em produzir com, poderíamos usar tais lacunas de todos, tais contradições diversas, para a transformação também do todo.

Comumente, Pernambuco fincava nossos pés no chão da realidade, mostrando-nos que aquele exercício que fazíamos, que muitas vezes gerava tal ruído que o exercício da construção do diálogo se tornava complicado e quase inexistente, era infinitamente mais ruidoso conforme aumentava o número de pessoas e de suas singularidades endereçadoras, por isso, era necessário amadurecer o uso da construção da consciência histórica, dos lugares comuns de fala como elos firmadores de possíveis lugares de reconhecimento coletivo, amadurecermos a criação de lugares de encontros comunicativos, ou socializadores, coerentemente com o que Freire traz (FREIRE, 2011). 
Pernambuco nos esclarecia que esse amadurecimento vinha com o contínuo movimento de, em nossas práticas coletivas, olhar para fora e para dentro quando lidávamos com o conhecimento coletivo, que nos impunha entender a função social do conhecimento científico, desconstruir o sentido da hierarquia opressiva, aprender que as estruturas opressivas não podem ser desconstruídas com socos e pontapés, pois consciência não se impõe a ninguém. É necessário a construção do encontro de sentido para poder lidar com a coletividade de forma freiriana, por isso "Ensinar e aprender são assim momentos de um processo maior - o de conhecer, que implica re-conhecer" (FREIRE, 1997, p. 24).

Nos quase quatro anos que tive a oportunidade de lidar com esse espaço e com a professora Pernambuco, seja nas aulas, seja em outros espaços não acadêmicos, uma vez que eu a adotei como minha confidente, pude não só ver meus saltos de compreensão como os saltos de muitos que decidiam acompanhar também o grupo. Em vários momentos, muitas das pessoas que compartilhavam esse espaço expunham criações de projetos engajadores em seus espaços de trabalho, outros tantos silenciosamente mudavam seus modos de ser, se tornando mais coletivos, mais acessíveis, menos competitivos.

Eu, como disléxica e pesquisadora em formação, que escondia minha singularidade por medo da rejeição dos meus pares, já que essa singularidade me determinava uma limitação com o instrumento do meu trabalho acadêmico, a linguagem, encontrei nesse espaço um lugar onde pude me trabalhar coletivamente, me desmarginalizar desmarginalizando o outro, me acolher acolhendo o outro. Entender as minhas limitações sendo sensível para a limitação do outro. Pude, no sentido prático, vivenciar a consciência elucidativa da minha dor com a dislexia e observar que muitos que não têm dislexia, mas têm limitações outras, reflexo da negação dos seus direitos de explorarem suas potencialidades nos limites dos seus poderes e desejos, são seres carregados de conhecimentos de mundo e, quando conquistam espaços de exploração de suas potencialidades, dão saltos inacreditáveis, se tornando seres muitas vezes mais inteiros do que muitos intelectuais eruditos que passam a vida em um mesmo horizonte de sentido existencial.

É sobre esse sentido de inteireza que se dá no estado de coletividade, estar com vivenciado, que é conquistado no processo de encontro com o outro, de construção de pontos comunicativos entre os diferentes, que acredito estar pautada também a obra Pedagogia do Oprimido, dada minha vivência com esse espaço descrito aqui. Uma inteireza que se indica quando Freire (2011) usa sentidos referenciais subjetivos como amorosidade, afetividade, boniteza, esperança, humanização, ousadia, vinculando-os a um quefazer transformador que tem como objetivo buscar "[...] a restauração da intersubjetividade" (FREIRE, 2011, p. 56). Inteireza germinada por meio de ações voltadas para a alteridade, por meio de círculos culturais, por meio da comunicação das leituras de mundo que desnaturalizam a ideologia opressora que mantém uma descrença no saber do outro ao considerar o diferente como incapaz diante de horizontes epistemológicos específicos (FREIRE, 2011). 
Por trás do sentido de existência freiriana há um "imperativo existencial e histórico" (FREIRE, 1997, p. 10) que se transforma na práxis ética do reconhecimento do outro, uma vivência profunda do estar "com". E esse caráter, na minha compreensão, era o elo significativo entre a construção do sentido teórico da obra de Freire e a vivência da ação do sentido proposto nas aulas coordenadas por Pernambuco no Ateliê. Há, na Pedagogia do Oprimido, a exposição da existência de ontologia freiriana, uma epistemologia freiriana que aqui escolhemos chamar de episteme para indicar sua reação não tradicional com a gnosiologia. Nessa episteme-gnosiológica em que se parte da inconclusão, da incompletude e do inacabamento dos seres vivos para se construir uma ontologia humana que caracteriza o humano pela vivência consciente da falta existencial. Falta que faz com que estejamos sempre em uma tensão entre ser e ser-mais. E era essa ontologia que, nos quatro anos em companhia do grupo GEPEM no Ateliê, testemunhei desdobrar-se em práxis pedagógica.

Freire (2011) irá explicar que só lidamos com a falta existencial na existência que nos impregna de vivência, por isso, parece ser, para Freire, essa falta que nos possibilita a criação de sentidos de ser e ser-mais na história, já que é a história o espaço de construção do ser-mais em transformação. Coerente a isso, Freire (1997), em tantos momentos afirmou que sua obra não podia ser vista como um método fechado. Ao mesmo tempo, afirmo que não nos dizemos conhecedores da filosofia de um filósofo por decorar seus conceitos, por saber citar e localizar nas suas obras os sentidos identificativos de sua filosofia, mas, ao contrário, conhecemos uma obra filosófica quando construímos o novo sobre ela, movendo seus sentidos para tornar novos sentidos umbilicais entre o berço significante e construído como significado (FREIRE, 2011). Assim, acredito que Pernambuco o fez como Freire, ao tentar passar para seus alunos e nas práticas que ela coordenava no Ateliê a Pedagogia do Oprimido pelo ângulo do processo de inteirar-se, por uma vivência ética do reconhecimento que proporciona conhecimento relacional, uma vez que proporciona o estar com.

E é por esse motivo que este trabalho busca reler a obra Pedagogia do Oprimido a partir da necessidade de tomada de consciência do estar com em sua duplicidade conceito-vivência libertadora, fazendo uso, como apoio, da vivência do Ateliê para mover nossa leitura sobre a realidade enraizadora, nos dando a possibilidade de trazermos para este trabalho o lugar de fala que encarna o exercício de reconhecimento coletivo. Por sua vez, esse lugar de fala do hoje será usado para focar no ângulo do estar com, apresentado na Pedagogia do Oprimido. Para isso, usar-se-ão trabalhos que falam sobre a obra Pedagogia do Oprimido de tal modo que nos ajudem a entender para além dos seus conceitos que norteiem a compreensão do sentido do estar com nessa obra. É o que será feito em seguida.

\section{A PEDAGOGIA DO OPRIMIDO E A CONSCIÊNCIA DO ESTAR COM}

Para começarmos essa releitura, é importante que ressalvemos as singularidades que fazem parte da criação da obra Pedagogia do Oprimido, contexto enraizador do sujeito 
Paulo Reglus Neves Freire (1921-1997) que, se não explica totalmente, ajuda a elucidar sua obra. Essas singularidades têm início nas vivências de uma infância humilde passada entre as áreas urbana e rural da cidade de Recife, no abandono da advocacia por única prática, que levou Freire a uma reflexão profunda sobre as estruturas de negação dos meios de organização social, e na chegada de um convite que o levou a ministrar aulas (FREIRE, 1997).

O sentimento vivo da carência do outro levou Freire a buscar na educação uma coerência entre seus valores subjetivos humanistas e a necessidade de ser-mais por meio do trabalho agente de transformação. O seu lugar de fala, o Nordeste, era marcado por uma taxa de analfabetismo exorbitante. Esses "sem fala" no mundo letrado naturalizavam-se como "sem mundo", determinados a se ajustar como desprovidos de saber. O proporcionar o alfabetismo em uma realidade em que tantos tinham suas existências negadas pela exclusão do universo das palavras tornara-se a via prática da transformação preconizada. Sobre isso, explicita Freire (1997, p. 54-55):

Daí que, no horizonte da alfabetização de adultos, por exemplo, eu me ache, desde faz muito tempo, insistindo no que venho chamando de "leitura do mundo e leitura da palavra", nem a leitura apenas da palavra, nem a leitura somente do mundo, mas as duas dialeticamente solidárias.

As práticas no universo da educação popular levaram Freire (2017) a começar a visibilizar o encontro com os excluídos do mundo letrado, mas cheios de fala de mundo, como meio pedagógico revolucionário, pois, em suas vivências, ele pode observar em ato a relação de inteireza que envolve o salto cognoscente do humano oprimido ao se descobrir dono de um criar deliberativo, abrindo-se, assim, para sua situação ontológica de estar com e no mundo. Essa consciência de interação mediativa, que nunca é completa, foi observada e amadurecida por Freire ao passar dos vários projetos como professor, alfabetizador e educador popular, vivências que lhe mostravam a relação entre o diálogo e o estado de existir como agente de mudança.

O diálogo sempre foi a principal fonte de inspiração de Paulo Freire. Ele construía seus pensamentos com base no diálogo, na constância da troca de saberes, defendia a necessidade de dialogar, de maneira horizontal sem diferenciar ou excluir umas ou demais partes do processo, para que se chegasse a um denominador comum maior, construído sempre pelo entendimento coletivo (SILVA, 2017, p. 23).

Se o diálogo é o ato visível da teoria da revolução de Paulo Freire, o estado de reconhecimento que nos coloca com é o todo invisível que se faz sentir como universo do possível intersubjetivo, por isso mesmo a relação entre o educador e o educando não pode se dar em distintas dimensões, em que o professor se coloque em um lugar e o aluno em outro. Consequentemente, o conhecimento termina por ser imposto de forma vertical na rea- 
lidade onde a interação meditativa é fragmentada. Freire, ao descobrir a palavra de mundo como meio pedagógico revolucionário, descobre também esse princípio ético do encontro como motor necessário, mas não suficiente, para a transformação revolucionária por meio do educar libertador, como podemos ver em toda a Pedagogia do Oprimido (2011), como também na Pedagogia da Esperança (1997). Essa obra expõe o seu testemunho de mundo, que tem o objetivo de explicar a trama que levou à escrita da Pedagogia do Oprimido.

É na Pedagogia de Esperança que compreendemos o real sentido revolucionário do diálogo na obra freiriana, quando Freire (1997) exibe a trama enraizadora que ele indica como motor da obra Pedagogia do Oprimido. Nessa trama existencial, o sentido que extrapola o conceito de diálogo pode ser visto como lugar de vivência conscientizante, onde a função do conceito não chega, como explica Adorno na dialética negativa (ADORNO, 2009) ao tratar do não conceito. Tal lugar que faz deslizar a funcionalidade formativa do conceito de diálogo é justamente a força do encontro com o outro.

O sentido de diálogo na Pedagogia do Oprimido encarna a vivência existencial cheia de encontros fiadores da trama que forma a vida de Freire. Um deles, que Freire afirma ter umedecido seu corpo até os dias da escrita do livro aqui mencionado, foi o encontro com o outro pela fala encarnadora do mundo desse outro diferente, que, ao ser questionado sobre a crueldade imbuída nos castigos em seu filho, Ihe responde dando como sentido do seu ato (para Freire, até ali, sem sentido) uma realidade que dela nada Freire sabia (FREIRE, 1997), mas que pela escuta comprometida se mostra parte de Freire por ser parte do mundo que ele compartilha com esse outro.

\begin{abstract}
O fato de jamais haver esquecido a trama em que se deu aquele discurso é significante. $\mathrm{O}$ discurso daquela noite longínqua se vem pondo diante de mim como se fosse um texto escrito, um ensaio que eu devesse constantemente revisitar. Na verdade, ele foi o ponto culminante no aprendizado há muito iniciado - o de que o educador ou educadora progressista, ainda quando, às vezes, tenha de falar ao povo, deve ir transformando o ao em com o povo. E isso implica o respeito ao "saber de experiência feito" de que sempre falo, somente a partir do qual é possível superá-la (FREIRE, 1997, p. 14).
\end{abstract}

No decorrer da obra Pedagogia da Esperança e da dissertação de Silva (2017), como de outras obras que expõem ações de fazer-ser do sujeito Freire, damos conta que o processo de enraizamento que umedeceu o corpo de Freire foi uma profunda experiência de estar com o outro, de estar com o mundo como fundo relacional ontológico, do ser sensível à realidade que nos coloca nele, mostrando o enraizamento como fenômeno nutrificador, resultado de nossa ação hominizante no mundo. Por isso, é o enraizamento que nos faz vivenciar o sentido de terra, de chão, de cor, de lar, de ser alguém temporal e espacial, como afirma Weil (2001) em sua obra O Enraizamento. A experiência de reconhecimento, como o processo de problematização descrita na Pedagogia do Oprimido (2011), nunca 
deixa ileso aquele que, problematizando, experiencia profundamente o fundo comum: "Os que passam têm de assumir uma forma nova de estar sendo; já não podem atuar como atuavam; já não podem permanecer como estavam sendo" (FREIRE, 2011, p. 66-67, grifos do autor).

A vivência do ter palavra para os excluídos do mundo das letras é o trincar a estrutura que os paralisam, que os imputam o peso do ser objeto vazio, sem mundo, sem conhecimento, sem palavra, sem som para a denúncia. $O$ processo de se perceber falante por meio das palavras geradoras não só vai familiarizando o sujeito ao mundo das famílias das sílabas, como levando o sujeito a contemplar seu mundo, codificação que, Ihe proporcionando uma vivência de pertencimento a um lugar, uma realidade cultural que o carrega na medida em que é carregado, Ihe abre um novo modo de olhar para si e para esse mundo. Mesmo aí está o encontro com, o invisível-sensível, uma vez que a codificação do mundo por meio da fala de mundo impõe uma revisitação, uma presentificação do mundo, fazendo o sujeito codificador se colocar com o mundo, quando ele the forma para si, e no mundo, quando essa formação Ihe endereça um lugar de endereçamento de si (FREIRE, 2011).

A problematização descodificadora leva o sujeito descobridor de sua fala de mundo a [re]construir sua realidade, de tal forma que os grilhões da determinação desnaturalizados do tempo-espaço histórico do sujeito se tornem motores do agir engajado revolucionário. Por isso mesmo, para Freire (1997), a consciência não é suficiente para a mudança, uma vez que "[...] o conhecimento mais crítico da realidade, que adquirimos através de seu desvelamento, não opera, por si só, a mudança da realidade" (FREIRE, 1997, p. 13), da mesma forma que a educação também não, mas tais são elementos necessários.

Coerentemente com o que foi já tratado, as situações-limites revividas pela presentificação da aprendizagem revolucionária abrem para os sujeitos da aprendizagem a possibilidade de se descobrirem juntos diante das contradições que negam as potencialidades dos desvelados. Consequentemente, "[...] será a partir da situação presente, existencial, concreta, refletindo o conjunto de aspiração do povo, que poderemos organizar o conteúdo programático da educação ou da ação política" (FREIRE, 2011, p. 119-120). Essa organização em coletividade do real vivido para além das impressões ingênuas deterministas é colocada como uma via de mão dupla, isto é, processo de aprendizagem em que há uma conquista do eu e do outro, porque está por trás dela um dos efeitos perceptivos de reconhecimento: um resultado do ontológico humano socializador que, criando tramas compartilhadas entre o coletivo, pode levar à concretização das criações dos seres partes.

Nós podemos dizer que todo o pensamento de Freire é perpassado por um imperativo de respeito à alteridade do outro, seu universo cultural e seu mundo da vida [...]. Toda a eticidade da existência humana se dá no reconhecimento da alteridade, da sua dignidade de pessoa [...]. Seguindo o legado ético-pedagógico de Freire, podemos concluir dizendo que o resgate da dignidade do outro, da sua alteridade 
é condição primeira para a edificação de um projeto de mundo/sociedade "em que seja menos difícil amar" (TROMBETTA, 2016, p. 35).

O conhecimento produto da humanidade entra nesse processo intersubjetivo como possibilitador do deslocamento do olhar e por isso gera o enlarguecimento do horizonte vivido do eu e do outro em inteiração relacional. Assim, o sujeito reconhece sua realidade, se abrindo para o estado de estar com o mundo e com o outro que expõe a sua realidade, vivenciam ambos a trama que os fia em estado de com, por tornarem possível, juntos, vivenciar novas estruturas cognoscentes de ler o mundo compartilhado pelas realidades plurais. A trama que envolve as realidades no mundo-fundo leva à conscientização das relações entre as partes e o todo. A relação entre a macroesfera deixa de ser ignorada na medida em que a microesfera já não é mais desconhecida, e passa processualmente a ser uma realidade do qual o sujeito faz parte e, fazendo parte, pode agir sobre, pode reivindicar mudanças concretas, fazendo uso de sua ação política. Vemos isso ao Freire proferir que "Só existe saber na invenção, na reinvenção, na busca inquieta, impaciente, permanente, que os homens fazem no mundo, com o mundo e com os outros" (FREIRE, 2011, p. 81).

A historicidade, que remonta ao tempo-espaço enraizador, não pode ser funcionalizada. Por estar em constante mudança, o fundo é devir, como entende Freire (2011), pois, assim como a ética, a historicidade se modifica à medida que o tempo/espaço muda. Hoje, a realidade oprimido/opressor ainda é um fato organizador da nossa realidade. Já não temos percentuais de analfabetismo como quando Freire escreveu Pedagogia do Oprimido, mas, hoje, lidamos com o analfabetismo funcional, pessoas que foram alfabetizadas dentro de formatos bancários e, não fazendo sentido as palavras que foram impostas às suas realidades, não foram internalizadas e não se tornaram instrumentos de mudança das vidas dos que ainda têm seus ser-mais negados. O devir que a história encarna nos impõe outros campos de batalha, nos impõe outras formas de militar em prol da transformação social. "O que pode e deve variar, em função das condições históricas, em função do nível de percepção da realidade que tenham os oprimidos, é o conteúdo do diálogo" (FREIRE, 2011, p. 73).

O silenciamento das massas oprimidas já não passa só pela falta do mínimo, pela necessidade de se ter leis que tornem as minorias visíveis para o Estado, passa também pelo acirramento do desenraizamento dos sujeitos, pelo processo de abstração dos meios opressivos que é formado por toda uma gama de fenômenos subjetivos que resultam no empobrecimento das relações afetivas dos sujeitos, na colonização de suas subjetividades, na superficialização dos encontros intersubjetivos. Toda essa gama de fenômenos de nosso tempo/espaço chega em graus diferentes em toda a sociedade brasileira, via a inclusão digital pelo barateamento das tecnologias de comunicação móveis que torna a internet acessível a vários grupos sociais.

Os fatos supracitados anteriormente devem ser somados às condições concretas de mudanças, posto que, como afirma o filósofo Byung-Chul Han (2015), saímos de uma fase histórica marcada por barreiras de exclusão explícitas, onde existiam os de fora e os 
de dentro, para nos vermos hoje em uma fase histórica em que o modo de exclusão se dá dentro de outros formatos, dentro de formatos abstratos, formatos virais. "O que me parece fundamental para nós [...] é a assunção de uma posição crítica, vigilante, indagadora, em face da tecnologia" (FREIRE, 1997, p. 68).

Han (2015, p. 17) segue explicando que, atualmente, lidamos com uma violência positiva que se caracteriza pela "[...] aniquilação suave, uma violência genética e de comunicação; uma violência do consenso". Ele denuncia, fazendo uso da sociologia de Jean Baudrillard (1929-2007) sobre a contemporaneidade, que o modo com que os objetos de comunicação são inseridos em todo o espaço/tempo da vida humana gera uma antipatia viral, ou uma inimizade diante do diferente. Mas devemos entender que não é qualquer diferente, mas o diferente que não compartilha os códigos de aceitação do consumo. É importante que compreendamos isso, já que existe uma supervalorização de uma diferença superficial, uma diferença que faz uso dos códigos de consumo.

A exclusão se faz, nessas novas estruturas do desempenho exacerbado, pela exaustão mental, tal que o sistema virtualizado emana continuamente estímulos opressivos que levam o sujeito a se desfazer de sua singularidade genuína, por uma diferença rasa. Estamos diante de uma "[...] violência sistêmica, isto é, uma violência imanente ao sistema" (HAN, 2015, p. 20), causadora de uma sociedade competitiva em que não há acolhimento, se não pelo valor do uso, da utilidade do outro para um fim produtivo. O estado de desencontro sistêmico leva a um ilhamento do indivíduo cismado com o outro. O ilhamento tem a ver com uma anulação das estruturas intersubjetivas que levam ao embarreiramento da alteridade: o outro só se torna aceitável se assimilado positivamente, isto é, hegemonizado.

A atenção profunda que tem a ver com o processo de enraizamento dá lugar a uma atenção rasa, uma hiperatenção. "Essa atenção dispersa se caracteriza por uma rápida mudança de foco entre diversas atividades, fontes informativas e processos" (HAN, 2015, p. 33) que, por sua vez, leva a uma pura inquietação, que também dificulta a contemplação codificadora. Sendo a hiperatenção uma reprodução rápida do já existente, ela não deixa lugar para o processo de criação problematizadora do reproduzido. Não se "tece mais e não se fia" (HAN, 2015, p. 34): a violência silenciosa gera o desaparecimento da experiência de ser, do "espanto a respeito do ser-assim das coisas" (HAN, 2015, p. 35), perde-se o poder da desinteriorização, "[...] o eu pós-moderno está totalmente isolado" (HAN, 2015, p. 44).

$\mathrm{O}$ isolamento do eu hiperativo gera uma "desnarrativização (Entnarrativisierung) geral do mundo", que passa a não existir de forma real, pois esse eu exausto sofre o "[...] cansaço solitário, é um cansaço sem mundo, destruidor de mundo" (HAN, 2015, p. 72). Esse eu exausto, ao se assemelhar ao movimento de necrofilia de que Freire fala (2001), nos faz observar que o cansaço da competitividade é destrutivo, pois, "E, ao assim procedermos, nos tornamos necrófilos, em lugar de biófilos. Matamos a vida, em lugar de alimentarmos a vida. Em lugar de buscá-la corremos dela" (FREIRE, 2001, p. 174). 
A violência silenciosa que o filósofo Byung Chul Han (2015) denuncia está ligada a todo um modo de vida voltado para a produção desmedida, marca do neoliberalismo, que se reflete na relação que a maioria de nós tem com os meios de tecnologia virtual quando esses se tornam instrumentos com um valor em si mesmo. Nas universidades, vemos mais claramente esse processo de desenraizamento em massa, pois é muito comum lidarmos com indivíduos que são exímios acumuladores de informação, mas não conseguem lidar com o outro. Desses que não conseguem lidar com o outro temos aqueles que não lidam com o outro por ensimesmamento - um medo de ser meio daquele que se aproxima -, e temos aqueles que não conseguem lidar com o outro porque não se deixam ser tocados por ele, já que o outro só ganha visibilidade se é meio para a aquisição. "Qualquer que seja a situação em que alguns homens proíbam aos outros que seja sujeito de suas buscas, se instaura como situação violenta. Não importando os meios usados para esta proibição. Faze-lo objetos é aliená-los de suas decisões, que são transferidas a outro ou outros." (FREIRE, 2011, p. 104).

No Ateliê Práticas Educativas em Movimento, era muito comum lidarmos de frente com o produto dessa violência silenciosa, pois era muito frequente a turma se dividir entre aqueles que entenderam os conceitos freirianos funcionalmente, e aqueles que não entenderam direito, já por não estarem completamente atrelados a esse fenômeno de desenraizamento e precisarem de tempo para construírem o sentido prático-teórico do que era apresentado a eles.

Nessas situações, os egos se exaltavam e muitos tentavam fazer uso de seus lugares de poder opressivo para não serem levados ao lugar de encontro com o outro. "A estrutura de seu[s] pensar se encontra condicionada pela contradição vivida na situação concreta, existencial, em que se 'formam'” (FREIRE, 2011, p. 44). Contudo, como o objetivo não era a aquisição de informação funcional, mas experimentar o sentido da práxis pedagógica freiriana, Pernambuco elaborava de tal forma a dinâmica de aula, usando os três momentos pedagógicos, que éramos levados a parar para esperar o tempo do outro, gerando uma inserção crítica da realidade de ilhamento.

A degustação da espera do tempo do outro nos levava a um lugar de desmonte da competição naturalizada, pois, na espera do tempo do outro, éramos levados ao tempo intermédios, o tempo do tornar visível o outro como fim e não como meio. Da mesma forma, esse processo acontecia com os exercícios de fala e de escuta, visto que, nesses momentos, os impulsos competitivos nos mostravam como monstros dilaceradores uns dos outros, mas, como nutrir uma competitividade se o importante ali não era a quantificação informativa, mas a práxis na coletividade do sentido internalizado?

Acredito que essa experiência no Ateliê pode nos indicar que, dadas as novas formas de exclusão em nossa realidade, em que temos que lidar com barreiras também subjetivas, nós, que somos conscientes da necessidade de militância em prol da transformação, devemos começar a nos preocupar também com questões subjetivas, questões que estão 
ligadas à práxis, mas se remetem mais ao âmbito do invisível relacional, questões que têm a ver com as conquistas dos meios necessários mas não suficientes, a construção dos metaespaços de intersubjetividade, uma vez que não podemos "[...] negar-lhe a importância que tem no processo de transformação do mundo, da história" (FREIRE, 2011, p. 51), negar o mérito dessa questão "[..] é cair num silogismo ingênuo" (FREIRE, 2011, p. 51).

Independentemente de estar falando de uma realidade em que se pressupõe a conquista de espaços de fala, o espaço acadêmico, os fenômenos causados pela violência silenciosa que o filósofo Han (2015) denuncia extrapolam os muros das universidades, passam pelas salas das escolas públicas dos centros urbanos, passam pelas próprias periferias do Brasil, e chegam a todos pelo coletivo imaginário construído a partir dos sentidos de desempenho.

Com efeito, na medida em que uma estrutura social se denota como estrutura rígida, de feição dominadora, as instituições formadoras que nela se constituem estarão, necessariamente, marcadas por seu clima, veiculando seus mitos e orientando sua ação no estilo próprio da estrutura. (FREIRE, 2011, p. 208).

Uma reportagem publicada no site da BBC-Brasil no dia 16 de julho de 2018, ao tratar sobre sintomas da imposição do desempenho desenfreado, afirma que os transtornos afetivos parecem ser sequelas de um modo de vida atual que faz o sujeito pressionar-se. Essa reportagem também afirmava, tendo como base uma pesquisa do lbope, que as classes mais vulneráveis a transtornos afetivos são as classes baixas, não só por os indivíduos dessas classes lidarem continuamente com situações muito estressantes envolvendo suas condições econômicas, mas também por existir uma ideia preconceituosa de que problemas envolvendo transtornos afetivos "não é coisa de pobre". Ela mostra que podemos estar lidando com outras situações do que Freire chama de necrofilia, em que se leva "[...] os homens ao ajustamento ao mundo" (2011, p. 91), inibindo o poder de criação por uma pseudoigualdade.

O processo de desenraizamento, que leva ao esvaziamento do real endereçador do indivíduo, leva também ao extremo, ao ilhamento e ao fenômeno da solidão na multidão. Esses são fenômenos com os quais já estamos lidando, e uma vez que esses fenômenos se tornam impedimentos para a construção do estado de com, logo eles se somam aos problemas envolvendo a conquista da construção das situações de transformação social: se não conseguimos vivenciar a intersubjetividade de forma consciente, se não conseguimos nos encontrar com o outro nem com a nossa realidade, se não conseguimos dialogar com o outro, se não conseguimos dialogar nossa militância, será sempre uma imposição e não uma ação política libertadora, mesmo que façamos a trajetória da vivência histórica que fia nossas tramas, pois essas são construções na intersubjetividade, elas impõem o estado de com, por isso mesmo a pedagogia do oprimido "[...] busca a restauração da intersubjetividade" (FREIRE, 2011, p. 56). 
A Pedagogia do Oprimido, por outro lado, nos indica meios de lidar com isso ao expor a necessidade do exercício de construção dos lugares de encontro. Os lugares de encontro não são necessariamente vivenciados com o sentido funcional do trazer o mundo, mas no sentido profundo do degustar a significância do mundo que, degustada como parte, se torna lugar do com compartilhado. É importante que a construção processual intersubjetiva, que indica que a historicidade não está sendo só verbalizada, mas encarnada de vivência subjetiva de enraizamento, seja exercitada de forma mais cuidadosa. É crucial que observemos com mais cautela os entre-espaços das práticas freirianas. Isso, por sua vez, expõe um estar atento à dimensão subjetiva das práticas freirianas, um sair do sentido produtivo das falas para lidar com o aprofundamento dos momentos de experienciação, lidar com os sinais coletivos de que se constroem, ali, falas tecedoras de tramas compartilhadas.

\section{CONCLUSÃO}

Assim como Freire (2011) falava sobre não existir uma receita determinada para a construção de uma educação libertadora, não existe também uma receita pronta para combatermos o fenômeno do desenraizamento. O que existe é a construção de exercícios de sensibilização diante do eu e do outro, exercícios que não são progressivos, mas processuais, que necessariamente impõem o lidar com os ruídos subjetivos da competitividade, impõem a localização, o desmonte e o rompimento com sentidos que se referenciam no princípio de desempenho opressivo. Por sua vez, isso deve nos levar a refletir sobre o modo de, verdadeiramente, construir espaços de encontros que proporcionem a experiência enraizadora, onde o trazer a historicidade construa fios religadores entre os indivíduos.

A obra Pedagogia do Oprimido, mesmo não sendo escrita em um contexto em que esse fenômeno fazia sentido completamente, responde a esse fenômeno quando fala que é necessário exercitarmos nossa fala-escuta endereçadas como meios de construção do encontro com os outros. Freire (2011), ao se propor expor o diálogo como instrumento de construção de uma consciência intersubjetiva, ou uma consciência de compartilhamento, nos indica caminhos para lutarmos contra os meios de exclusão gerados por essa violência silenciosa. Entra, aí, a importância de visibilizarmos esse conceito-vivência do estar com em toda sua pluralidade de sentido. E, como foi necessário para a visibilização desse conceito-vivência, do estar com, é necessário que saiamos das leituras senso comum dessa obra. É necessário que, assim como aconteceu na experiência proporcionada pelo Ateliê Práticas Educativas em Movimento, coordenado por Pernambuco e pelo grupo GEPEM, nós, freirianos, comecemos a observar com mais cuidado a dimensão invisível da práxis pedagógica freiriana com o objetivo de ficarmos atentos e atentas a possíveis esvaziamentos dos seus sentidos práticos humanistas.

Lembremos que o estar sendo nos impõe ação sobre aquilo que já foi posto, impõe revisão do que acreditamos estarmos fazendo certo, impõe olhar para a realidade e locali- 
zarmos as urgências que envolvem as estruturas de exclusão. As palavras só fazem sentido quando encarnamos nelas sentidos de referências, por isso a fala, a palavra impregnada de experiência de mundo, a escuta acolhedora e os encontros vinculadores são instrumento de libertação na obra freiriana. Assim, abrimos a problematização coletiva sobre como nos movermos diante dessas novas estruturas de exclusão em prol da germinação da busca pela inteireza relacional, que nos aproxima na medida em que descobrimos o outro como soma, como possibilidade de enlarguecimento, não por assimilação, mas por mediação relacional.

O momento histórico denuncia um movimento de sofisticação da opressão, onde os sonhos são impossibilitados pelo esvaziamento da experiência de profundidade relacional da subjetividade, devemos entender que "é impossível existir sem sonhos" (FREIRE, 2001, p. 35). Revela-se de profunda importância revisarmos os modos de luta contra a opressão diante desse novo modo de violência silenciadora. Busquemos, pois, estar atentos para a dimensão subjetiva das práxis pedagógicas freirianas para que não corramos o risco de estarmos calcificando o já dado, desse modo, minando as bases de sustentação da teoria revolucionária freiriana. Lembremos que "É na história como possibilidade que a subjetividade, e relação dialético-contraditória com a objetividade, assume o papel do sujeito e não só de objeto das transformações do mundo" (FREIRE, 2001, p. 51). 


\section{REFERÊNCIAS}

ADORNO, Theodor. Dialética Negativa. Rio de Janeiro: Zahar, 2009. Disponível em: <http://www. armazem3bruxas.com.br/images/ebooks/Dialetica\%20Negativa.pdf>. Acesso em: 23 jan. 2016.

BECKER, Fernando. Epistemologia. In: STRECK, Danilo R.; REDIN, Euclides; ZITKOSKI, Jaime José (org.). Dicionário Paulo Freire. 3. ed. Belo Horizonte: Autêntica, 2016. p. 152-154.

COSTA, Bruno Botellho. Trânsito/ transitividade. (Sociedade). In: STRECK, Danilo R.; REDIN, Euclides; ZITKOSKI, Jaime José (org.). Dicionário Paulo Freire. 3. ed. Belo Horizonte: Autêntica, 2016, p. 408-409.

DELIZOICOV, Demétrio; ZANETIC, João. A proposta de interdisciplinaridade e o seu impacto no ensino municipal de $1^{\circ}$ grau. In: PONTUSCHKA, Nídia Nacib (org.). Ousadia no Diálogo: interdisciplinaridade na escola pública. São Paulo: Loyola, 1993. p. 9-35.

FIORI, Ernani Maria. Aprender a dizer a sua palavra (Prefácio). In: FREIRE, Paulo. Pedagogia do Oprimido. 50. ed. Rio de Janeiro: Paz e Terra, 2011, p. 11-30.

FREIRE, Paulo. Pedagogia da Esperança: um reencontro com a Pedagogia do Oprimido (e-book). Rio de Janeiro: Paz e Terra, 1997. Disponível em: <http://peadanosiniciais.pbworks.com/f/Pedagogia_da_Esperanca_-_Paulo.pdf>. Acesso em: 20 dez. 2015.

Pedagogia dos Sonhos Possíveis. São Paulo: UNESP, 2001.

Educação como Prática da liberdade. 27. ed. Rio de Janeiro: Paz e Terra, 2003.

Pedagogia do Oprimido. 50. ed. Rio de Janeiro: Paz e Terra, 2011.

2015a.

Ação cultural para a liberdade e outros escritos. 15. ed. Rio de Janeiro: Paz e Terra,

Extensão ou Comunicação?. 17. ed. Rio de Janeiro: Paz e Terra, 2015b.

GOUVÊA, Antônio Fernando. O currículo na práxis da Educação popular: projeto pedagógico interdisciplinar- tema gerador via temática. In: PERNAMBUCO, Marta Maria; PAIVA. Irene Alves (org.). Práticas Coletivas na Escola. Campinas: Mercado de Letras, 2013. p. 75-96.

GOUVÊA, Antônio Fernando; DELIZOICOV, Demétrio; BRICK, Elizandro Maurício; PAIVA, Irene Alves; MOLINA, Mônica Castagna. A importância da práxis intelectual militante de Marta Pernambuco: Destaques Iniciais. Cadernos CIMEAC, Uberaba, v. 8, n. 1, p. 19-49, 2018.

HAN, Byung-Chul. Sociedade do cansaço. Petrópolis: Vozes, 2015.

LOSSO, Adriana R. Sanceverino. Intersubjetividade. In: STRECK, Danilo R.; REDIN, Euclides; ZITKOSKI, Jaime José (org.). Dicionário Paulo Freire. 3. ed. Belo Horizonte: Autêntica, 2016. p. 230-231. 
A práxis de estar com: a Pedagogia do Oprimido...

MARQUES, Thaís. O estigma enfrentado nas periferias pelas pessoas com depressão: pobre não pode se dar ao luxo de não sair da cama. BBC- Brasil. 15 julho 2018. Disponível em: <https://www. bbc.com/portuguese/geral-44400381>. Acesso em: 22 jul. 2018.

PERNAMBUCO, Marta Maria. A construção do Programa Escolar via tema gerador. In: PERNAMBUCO, Marta Maria; PAIVA, Irene Alves (Org.). Práticas Coletivas na Escola. Campinas: Mercado de Letras, 2013. p. 55-74.

PITANO, Sandro. Sujeito Social. In: STRECK, Danilo R.; REDIN, Euclides; ZITKOSKI, Jaime José (Org.). Dicionário Paulo Freire. 3. ed. Belo Horizonte: Autêntica, 2016, p. 384-385.

PUCCI, Bruno. A dialética negativa enquanto metodologia de pesquisa em educação: atualidades. Revista e-curriculum, São Paulo, v. 8, n. 1, abril 2012. Disponível em: <https://revistas.pucsp.br/ curriculum/article/view/9030/6630>. Acessado em: 23 jan. 2014.

SILVA, Camila Teo da. A gênese da pedagogia do oprimido: o manuscrito. Dissertação (Mestrado em Letras) - Faculdade de Filosofia, Letras e Ciências Humanas, Universidade de São Paulo, São Paulo, 2017.

TROMBETTA, Sérgio. Alteridade. In: STRECK, Danilo R.; REDIN, Euclides; ZITKOSKI, Jaime José (org.). Dicionário Paulo Freire. 3. ed. Belo Horizonte: Autêntica, 2016. p. 34-36.

WEIL, Simone. O Enraizamento. Bauru: EDUSC, 2001. 